Jurnal Perikanan (2021) Volume 11. No. $1: 26-34$

DOI : https://doi.org/10.29303/jp.v11i1.216

\title{
IDENTIFIKASI JENIS DAN KELIMPAHAN GASTROPODA DI PANTAI TELUK SEPANG KOTA BENGKULU
}

\author{
IDENTIFICATION OF TYPES AND ABUNDANCE OF GASTROPODE IN THE \\ BEACH OF SEPANG BEACH, BENGKULU CITY
}

\author{
Riski Slamet*), Dewi Purnama, Bertoka Fajar SP Negara \\ Program Studi Ilmu Kelautan Universitas Bengkulu
}

Jalan WR. Supratman Kandang Limun Kota Bengkulu, 38371 - INDONESIA

${ }^{*}$ Alamat korespondensi : rizki210195@gmail.com

\begin{abstract}
Abstrak
Laut merupakan penyedia sumber daya alam yang produktif, slaah satunya dalah Gastropoda. Kelompok hewan ini banyak terdapat di Kota Bengkulu karena secara geografis, Kota Bengkulu memiliki garis pantai yang panjang. Penelitian tentang jenis dan kelimpahan Gastropoda yang berada di Pantai Teluk Sepang Kota Bengkulu belum pernah dilakukan, padahal perairan ini merupakan daerah yang dipenuhi dengan berbagai aktivitas manusia, sehingga berkemungkingan besar mempengaruhi keanekaragaman Gastropoda. Oleh karena itu, penelitian ini penting untuk dilakukan agar dapat memberi informasi tambahan tentang jenis dan kelimpahan Gastropoda yang berada di Pantai Teluk Sepang Kota Bengkulu. Penelitian ini dilaksanakan pada bulan Juni-Juli 2020. Identifikasi Gastropoda dilakukan di laboratorium Perikanan Universitas Bengkulu. Metode yang digunakan dalam penelitian ini adalah metode survei. Pada penelitian ini terdapat 3 titik sampling pengamatan. Setiap titik sampling ditarik 2 transek garis secara horizontal dari pantai yang mengarah ke laut. Data yang diperoleh dianalisis menggunakan buku identifikasi : The living marine resources of the western central pacific and seagrass identification sheets and key (1998). Pada penelitian ini dapat disimpulkan bahwa di daerah perairan Teluk Sepang Kota Bengkulu terdapat sembilan jenis Gastropoda dengan kelimpahan yaitu 216 ind $/ \mathrm{m}^{2}$ Cerithidea cingulata, $7 \mathrm{ind} / \mathrm{m}^{2}$ Natica gualteriana, $3 \mathrm{ind} / \mathrm{m}^{2}$ Trochusconus, $8 \mathrm{ind} / \mathrm{m}^{2}$ Turbo chrysostomus, $7 \mathrm{ind} / \mathrm{m}^{2}$ Telescopium telescopium, $9 \mathrm{ind} / \mathrm{m}^{2}$ Strombus labiatus, 162 $\mathrm{ind} / \mathrm{m}^{2}$ Cerithidea obtuse, $3 \mathrm{ind} / \mathrm{m}^{2}$ Vexillum rugosum, dan $164 \mathrm{ind} / \mathrm{m}^{2}$ Cerithide aquadrata.
\end{abstract}

Kata Kunci : gastropoda, kota bengkulu, kelimpahan, identifikasi

\begin{abstract}
The sea is a provider of productive natural resources, one of which is gastropods. This group of animals is widely found in Bengkulu City because geographically, Bengkulu City has a long coastline. Research on the type and abundance of Gastropods in the Teluk Sepang Beach, Bengkulu City has never been carried out, even though these waters are an area filled with various human activities, so it is likely to affect the diversity of Gastropods. Therefore, this research is important to be carried out in order to provide additional information about the types and abundance of gastropods located on the Teluk Sepang Beach, Bengkulu City. This research was carried out in June-July 2020. Gastropod identification was carried out at the Bengkulu University Fisheries laboratory. The method used in this study is a survey method. In this research, there are 3 observation sampling points. Each sampling point is drawn 2 transect lines horizontally from the coast that leads to the sea. The data obtained
\end{abstract}


were analyzed using the identification book: The living marine resources of the western central pacific and seagrass identification sheets and key (1998). In this study it can be concluded that in the waters of Sepang Bay, Bengkulu City, there are nine types of gastropods with an abundance of $216 \mathrm{ind} / \mathrm{m} 2$ Cerithidea cingulata, $7 \mathrm{ind} / \mathrm{m}^{2}$ Natica gualteriana, $3 \mathrm{ind} / \mathrm{m}^{2}$ Trochusconus, $8 \mathrm{ind} / \mathrm{m}^{2}$ Turbo chrysostomus, $7 \mathrm{ind} / \mathrm{m}^{2} \mathrm{~m} 2$ Telescopium telescopium, $9 \mathrm{ind} / \mathrm{m} 2$ Strombus labiatus, $162 \mathrm{ind} / \mathrm{m} 2$ Cerithidea obtuse, 3 $\mathrm{ind} / \mathrm{m} 2$ Vexillum rugosum, and $164 \mathrm{ind} / \mathrm{m} 2$ Cerithide aquadrata.

Key words : gastropod, bengkulu city, abundance, identification

\section{PENDAHULUAN}

Laut merupakan penyedia sumber daya alam yang produktif. Wilayah pesisir dan lautan merupakan tumpuan harapan manusia dalam pemenuhan kebutuhan di masa sekarang dan akan datang. Salah satu sumber daya laut yang cukup potensial untuk dapat dimanfaatkan adalah Gastropoda. Gastropoda adalah salah satu kelas dari Moluska yang diketahui berasosiasi dengan baik terhadap ekosistem lamun.

Provinsi Bengkulu adalah salah satu provinsi di Indonesia yang mempunyai wilayah pesisir dan garis pantai yang sangat panjang. Berbagai potensi pesisir di Bengkulu salah satunya adalah Pantai Teluk Sepang. Kota Bengkulu merupakan salah satu daerah yang memiliki potensi pesisir yang sangat banyak karena kondisi daerahnya memiliki garis pantai yang panjang, Sehingga banyak terdapat hewan laut seperti gastropoda.

Gastropoda merupakan keong yang
bernilai ekonomis tinggi karena cangkangnya diambil sebagai bahan untuk perhiasan dan cinderamata, sedangkan dagingnya merupakan makanan yang lezat.Beberapa jenis keong yang bernilai ekonomis diantaranya dari famili Strombidae, Cypraeidae, Olividae, Conidae, dan Tonnidae (Mudjiono dan Sudjoko, 1994).
Penelitian tentang jenis dan kelimpahan Gastropoda yang berada di Pantai Teluk Sepang Kota Bengkulu belum pernah dilakukan, padahal perairan ini merupakan daerah yang dipenuhi dengan berbagai aktivitas manusia, sehingga berkemungkingan besar mempengaruhi keanekaragaman Gastropoda. Oleh karena itu, penelitian ini penting untuk dilakukan agar dapat memberi informasi tambahan tentang jenis dan kelimpahan Gastropoda yang berada di Pantai Teluk Sepang Kota Bengkulu.

Mempelajari pentingnya manfaat Gastropoda, maka diperlukan adanya kajian tentang hewan tersebut. Oleh karena itu peneliti tertarik untuk melakukan penelitian mengenai hewan Gastropoda yang meliputi jenis dan kelimpahan gastropoda di perairan Kota Bengkulu khususnya di Pantai Teluk Sepang Kota Bengkulu. Manfaat penelitian ini dapat memberikan informasi mengenai jenis dan kelimpahan gastropoda yang ada diperairan Pantai Teluk Sepang Kota Bengkulu.

\section{METODE PENELITIAN}

\section{Waktu dan Tempat Penelitian}

Penelitian ini dilaksanakan di Pantai Teluk Sepang, Provinsi Bengkulu. Penelitian ini dilaksanakan pada bulan JuniJuli 2020. Identifikasi Gastropoda dilakukan di laboratorium Perikanan Universitas Bengkulu. 


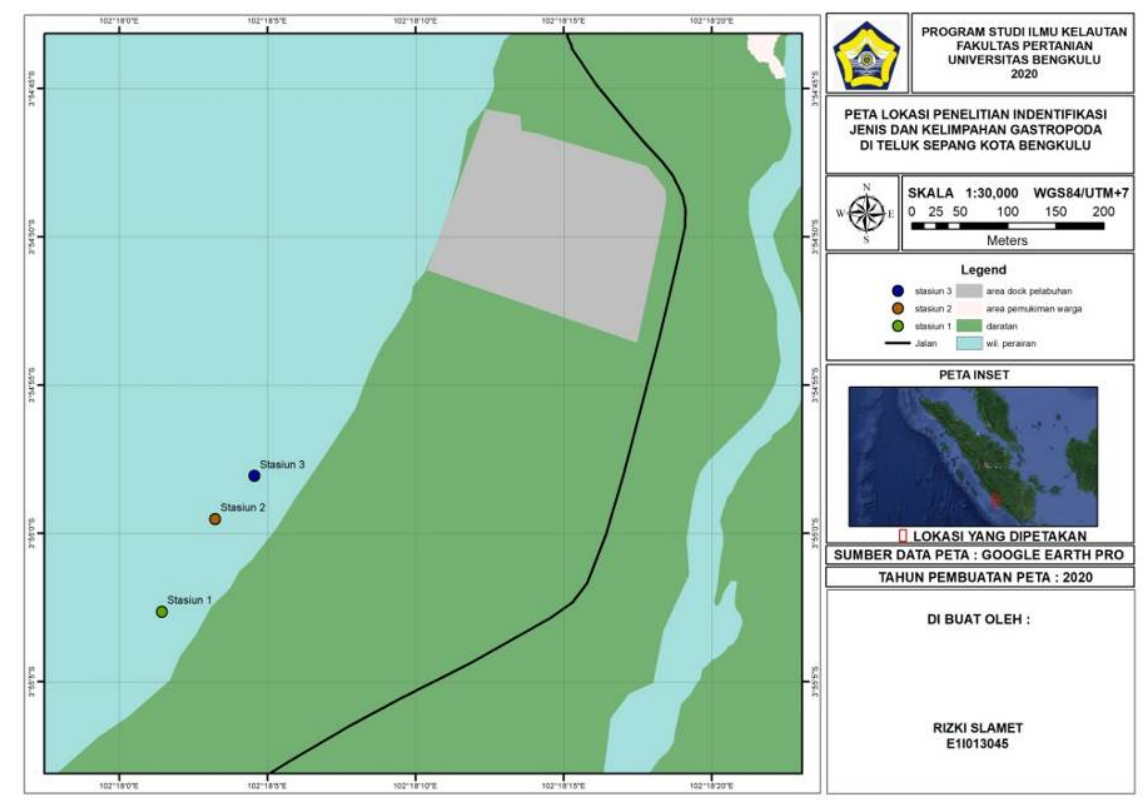

Gambar 1. Peta Lokasi Penelitian

\section{Alat dan Bahan}

Tabel 1. Daftar alat yang digunakan pada saat penelitian

\begin{tabular}{|c|c|c|}
\hline No & Nama & Kegunaan \\
\hline 1. & $\begin{array}{l}\text { GPS (Global Positioning } \\
\text { System) }\end{array}$ & Menentukan titik posisi pengamatan \\
\hline 2. & Roll meter & Mengukur jarak stasiun pengamatan \\
\hline 3. & Transek $1 \times 1$ meter & Plot contoh \\
\hline 4. & Tali raffia & Membuat jalur transek \\
\hline 5. & Termometer & Mengukur suhu \\
\hline 6. & Hand Refractometer & Mengukur salinitas \\
\hline 7. & Kertas $\mathrm{pH}$ & Mengukur $\mathrm{pH}$ \\
\hline 8. & Kamera & Dokumentasi \\
\hline 9. & Alat tulis & Mencatat data \\
\hline
\end{tabular}

Tabel 2. Daftar bahan yang digunakan dan kegunaannya dalam penelitian

\begin{tabular}{lll}
\hline No & Bahan & Kegunaan \\
\hline 1. & Aquadest & Membersihkan alat yang digunakan \\
2. & Kantong plastik & Menyimpan sampel Bivalvia \\
3. & Tisu & Membersihkan alat yang digunakan \\
4. & Bivalvia & Objek penelitian \\
5. & Buku identifikasi & Sebagai acuan identifikasi \\
\hline
\end{tabular}

\section{Metode Pengambilan Data}

Metode yang digunakan dalam penelitian ini adalah metode survei. Metode survei merupakan metode yang digunakan untuk mendapatkan data dari tempat tertentu yang alamiah dalam pengumpulan data (Sugiyono, 2009). Data yang dikumpulkan meliputi data jenis dan kelimpahan Bivalvia.

\section{Metode Pengambilan Sampel Penentuan Titik Sampling}

Pada penelitian ini terdapat 3 titik sampling pengamatan. Peletakkan titik sampling 1 terletak di bibir pantai dekat hutan bakau pantai Teluk sepang. Titik sampling 2 terletak 200 meter disebelah titik sampling 1 dan titik sampling 3 
terletak 200 meter di sebelah titik sampling 2. Setiap titik sampling ditarik 2 transek garis secara horizontal dari pantai yang mengarah ke laut. Jarak antara dua transek garis yaitu $200 \mathrm{~m}$, masing-masing transek garis terdapat lima transek kuadrat dengan ukuran $1 \mathrm{~m} \times 1 \mathrm{~m}$. Jarak antara transek kuadrat yaitu $30 \mathrm{~m}$.

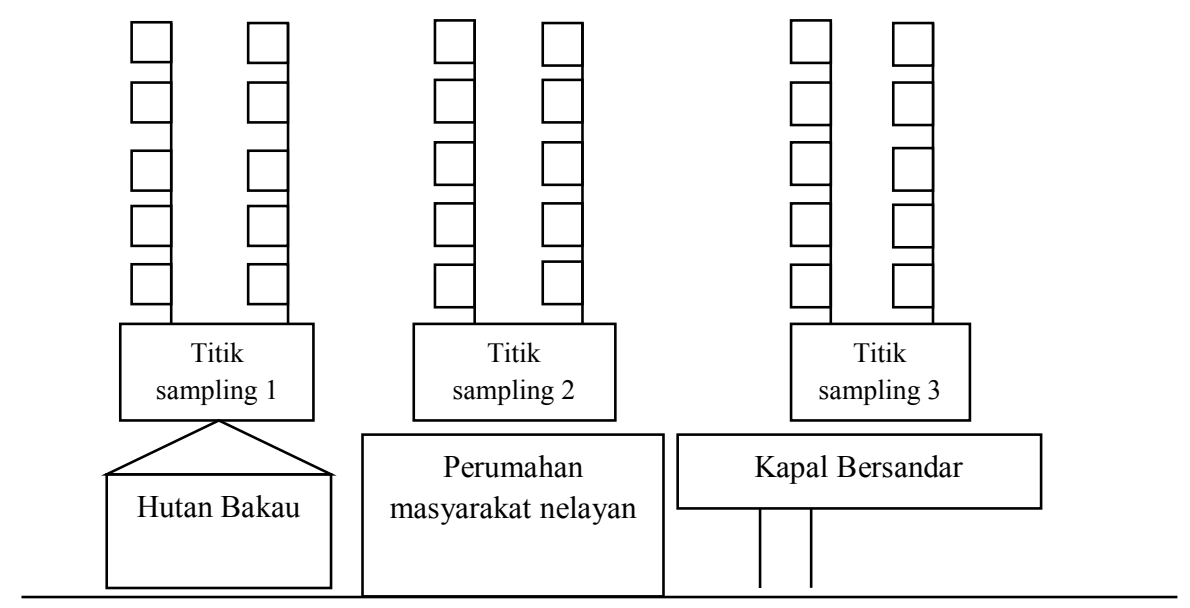

\section{Sampling Gastropoda}

Gambar 2. Titik sampling pengambilan data

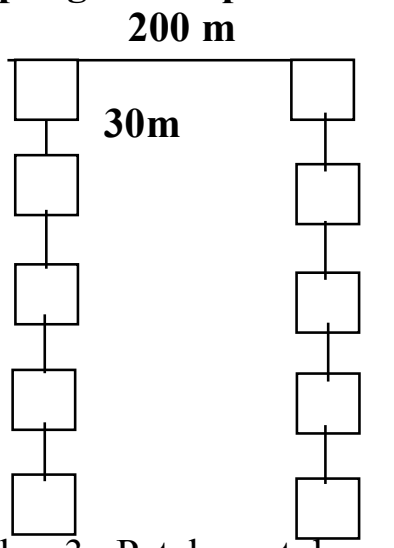

\section{Transek kuadrat 1 m x 1 m}

Gambar 3. Petak contoh yang digunakan untuk pengambilan sampel jenis dan kelimpahan Gastropoda

\section{Sampling Jenis dan Kelimpahan Gastropoda}

Sampling Bivalvia dilakukan dengan cara mengamati Gastropoda yang ada dalam transek kuadrat. Gastropoda yang masuk dalam transek kuadrat selanjutnya akan diamati jenis dan jumlahnya. Selanjutnya sampel akan diamati dan difoto untuk proses identifikasi.

\section{Pengambilan Data Parameter Lingkungan}

Dilakukan pengukuran parameter perairan yang meliputi: suhu, salinitas, $\mathrm{pH}$ (derajat keasaman), dan substrat.
Pengukuran parameter dilakukan secara langsung pada tiap stasiun yang telah ditentukan dengan tiga kali pengulangan pengukuran pada masing-masing stasiun.

\section{Analisis Data}

Data yang dianalisis pada penelitian ini meliputi jenis dan kelimpahan Bivalvia. Buku identifikasi yang digunakan adalah FAO: The living marine resources of the western central pacific and seagrass identification sheets and key (1998). 


\section{Analisis Kelimpahan Bivalvia}

Kelimpahan individu Gastopoda mengacu pada Fachrul (2007) yaitu :

$\mathrm{Di}=\mathrm{Ni} / \mathrm{A}$

Keterangan :

Di : Kelimpahan jenis (ind/m); Ni : Jumlah spesies jenis ke-i (ind); A : luas area pengamatan $(\mathrm{m})$

\section{HASIL DAN PEMBAHASAN}

\section{Karakteristik Lokasi Penelitian}

Penelitian ini dilakukan di Pantai Teluk Sepang, Kecamatan Kampung Melayu, Kota Bengkulu dan terdiri dari 3 titik sampling yang mewakili lokasi dalam penelitian. Banyak aktivitas bongkar muat kapal tongkang batu bara di lingkungan perairan Teluk Sepang, namun lingkungan perairan masih tetap dalam keadaan normal. Pantai Teluk Sepang memiliki luas perairan lebih kurang 1 ha.

Tabel 3. Hasil pengamatan transek pada setiap titik sampling

\begin{tabular}{llccc} 
No. & \multicolumn{1}{c}{ Spesies } & \multicolumn{3}{c}{ Titik sampling } \\
& & Ts I & Ts II & Ts III \\
\hline 1 & Cerithidea cingulata & + & + & + \\
2 & Naticagu alteriana & + & + & + \\
3 & Nerita undata & + & - & - \\
4 & Turbo chrysostomus & + & + & + \\
5 & Telescopium telescopium & + & + & - \\
6 & Strombus labiatus & - & + & - \\
7 & Cerithidea obtuse & + & + & + \\
8 & Cerithidea alata & + & + & - \\
9 & Cerithidea quadrata & + & + & + \\
\hline
\end{tabular}

\section{Deskripsi Jenis Gastropoda}

\section{Cerithidea cingulata}

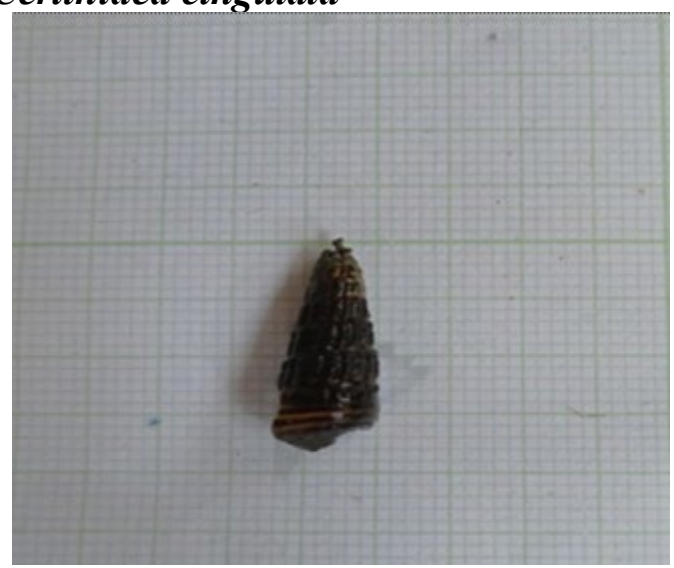

Gambar 4. Cerithidea cingulata

Memiliki panjang antara $4-6 \mathrm{~cm}$ dengan bentuk cangkang memanjang. Warna cangkang kehitaman dengan apeks agak meruncing dan lekuk sifon agak lebar serta permukaan cangkang kasar bertonjolan beralur. Tinggi cangkang maksimum $4.5 \mathrm{~cm}$. Cerithidea cingulata umumnya hidup di zona intertidal, terutama pantai berlumpur, pantai berpasir, dan di hutan mangrove (Laksmana, 2011).

\section{Natica gualteriana}

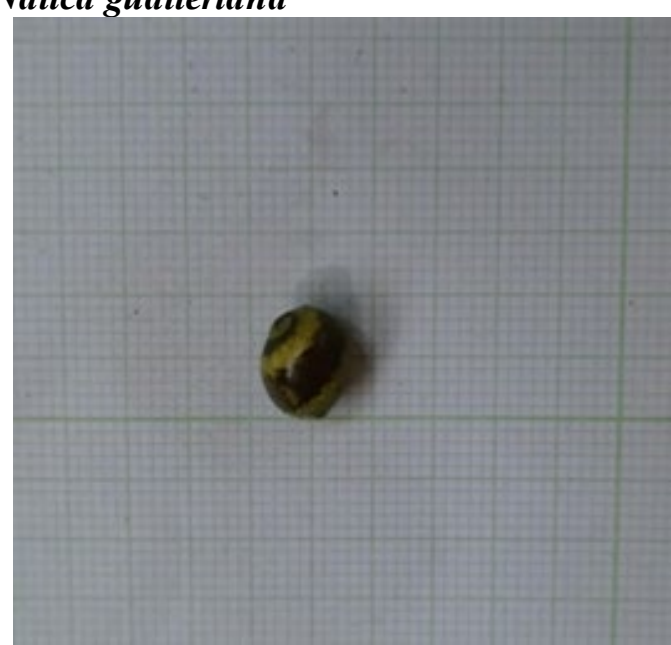

Gambar 5. Natica gualteriana 


\begin{abstract}
Memiliki cangkang yang bentuknya seperti bulat telur-kerucut, spire rendah dengan beberapa uliran, body whorl besar. Habitat di pasir atau lumpur. Memiliki panjang antara $0,5-1,5 \mathrm{~cm}$ dengan bentuk cangkang yang pendek serta warna cangkang yang coklat keemasan. Spesies ini agak meruncing dengan lekuk sifon yang agak lebar dan permukaan cangkang halus licin.
\end{abstract}

\section{Nerita undata}

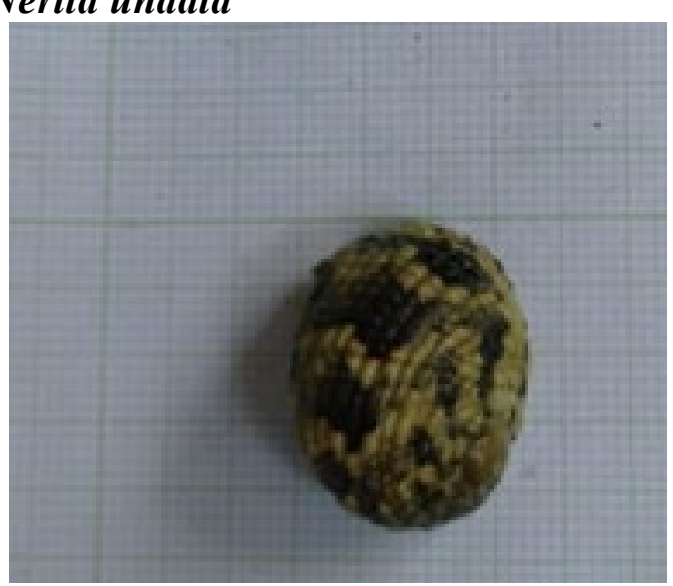

Gambar 6. Nerita undata

Bentuk tubuh polymorphic, terdiri atas variasi warna dan ukuran pola yang juga variatif. Atas dasar ini sehingga ditemukannya beberapa spesies baru meskipun ukuran dan motif sepintas tidak memiliki perbedaan yang berarti. Ada yang bentuk umumnya meruncing bagaikan duri yang tajam, ada bentuk cangkang berbentuk ulir. Corak dan tipe pada cangkang (sculpture) tidak terlalu dalam, berbentuk element-element spiral. Pada bagian inner lip terdapat 1 sampai 4 buah gigi berwarna putih dengan bentuk seperti proyeksi. Operculum berupa calcareous (bersifat keras), dengan pasak seperti proyeksi (projecting peg) pada bagian ujung dalam.

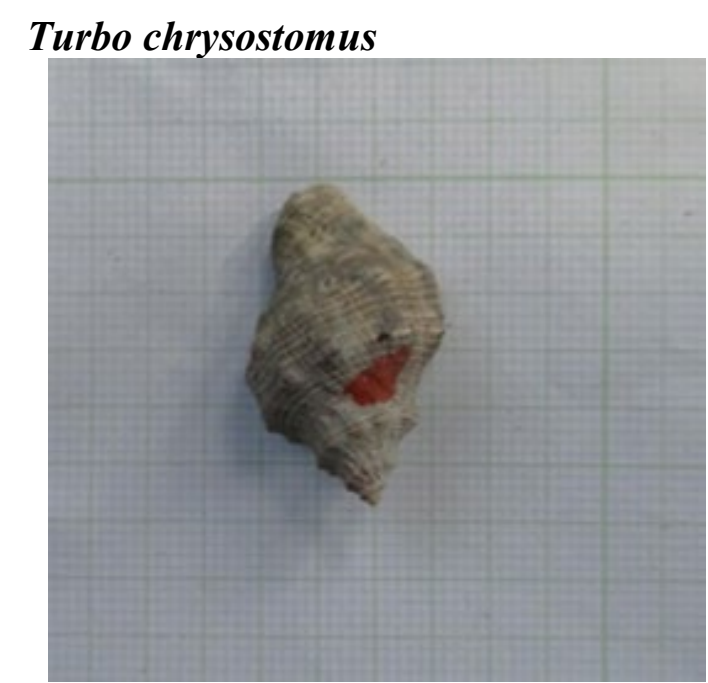

Gambar 7. Turbo chrysostomus

Turbo chrysostomus cangkangnya berbentuk spiral agak bulat dan berat serta sangat keras dan kuat, panjang cangkang sekitar 5,1 cm dan lebar cangkang sekitar $3,4 \mathrm{~cm}$, warna cangkang bagian luar coklat, sedangkan bagian dalam kuning dengan bagian outerlip berwarna putih. Arah putaran cangkang dekstral. Permukaan cangkang kasar karena ada guratan yang searah dengan putaran cangkang. Tipe operkulum calcareous yang keras.

\section{Telescopium telescopium}

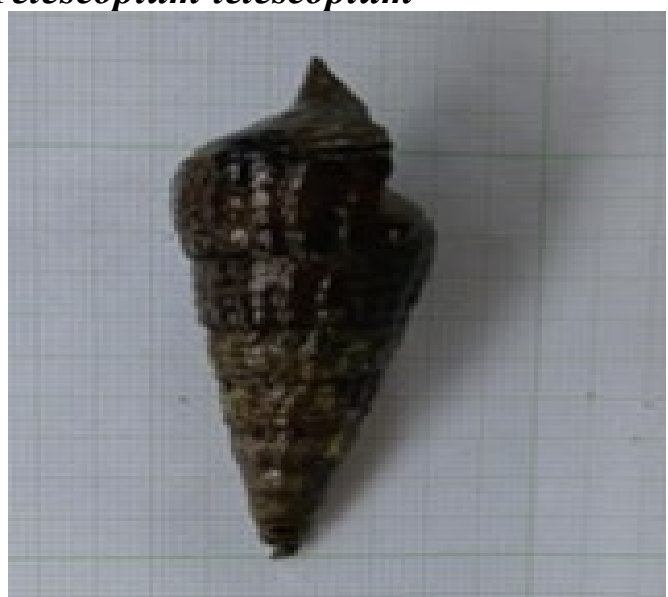

Gambar 8. Telescopium telescopium

Memiliki panjang cangkang berkisar antara $10-14 \mathrm{~cm}$ dengan bentuk cangkang memanjang. Spesies ini memiliki warna cangkang kehitaman dengan apeks yang agak meruncing dan 
lekuk sifon yang agak lebar. Permukaan cangkang spesies ini kasar dan beralur secara vertikal.

\section{Strombus labiatus}

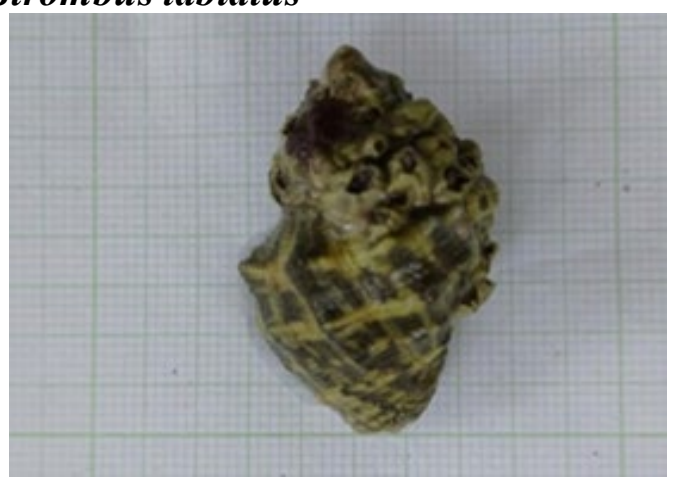

Gambar 9. Strombus labiatus

Memiliki cangkang tebal dan padat, dengan body whorl relatif besar dan bentuknya variabel. Periostrakum sebagian besar tipis dan beludru. Operculum tebal. Habitat di daerah tropis, subtropis, di perairan dangkal, berpasir, berlumpur atau puing-puing dasar laut. Memiliki panjang antara $2-4 \mathrm{~cm}$ dengan bentuk cangkang pendek dan memiliki warna dominan putih dan hitam. Spesies ini memiliki apeks yang runcing dengan lekuk sifon yang agak lebar serta permukaan cangkang yang kasar bertonjolan.

\section{Cerithidea obtuse}

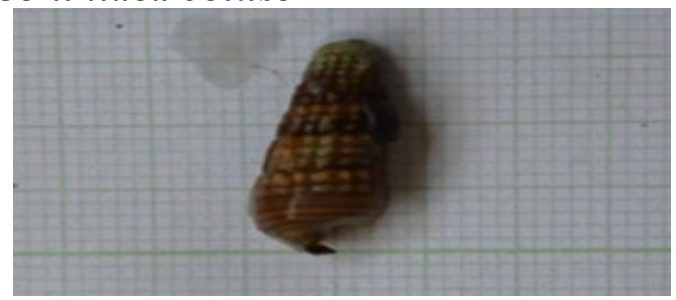

Gambar 10. Cerithidea obtusa

Spesies ini memiliki panjang cangkang antara 6-9 $\mathrm{cm}$ dengan bentuk cangkang memanjang dan memiliki warna cangkang didominasi garis- garis coklat. Apeks spesies ini agak meruncing dengan lekuk sifon yang agak lebar dan tebal. Permukaan cangkang kasar bertonjolan pada setiap alurnya.

\section{Cerithidea alata}

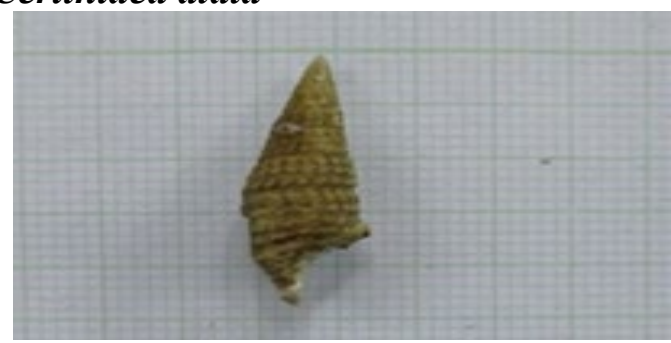

Gambar 11. Cerithidae alata

Lebar cangkang $1.5 \mathrm{~cm}$, rata-rata lebar kolumela $2.1 \mathrm{~cm}$, rata-rata tinggi aperture $2.3 \mathrm{~cm}$, dan lebar aperture ratarata $1 \mathrm{~cm}$. Memiliki tipe operculum dekstral dan arah putaran cangkang multispiral. Pada masing-masing jenis yang ditemukan memiliki motif cangkang berwarna hijau krem kecoklatan, bentuk kerucut dengan sudut runcing menyempit, permukaan cangkang berbintik-bintik.

\section{Cerithidea quadrata}

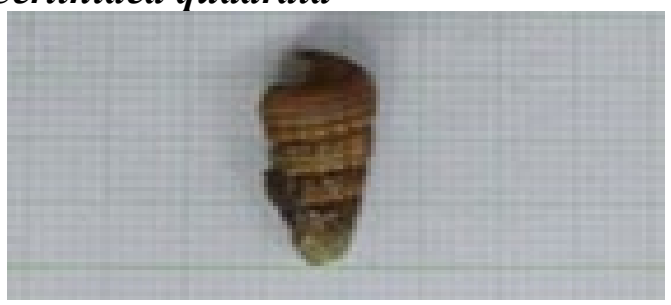

Gambar 12. Cerithidae qudrata

Memiliki ciri-ciri seperti cangkang tebal, padat dan meruncing, tingginya mengerucut, body whorl sedikit cembung. Periostrakum kecoklatan, operculum membulat, kepala dan sepasang tentakel menyempit di daerah distal, kaki depan membulat dan kaki belakang tumpul. Ditemukan di lingkungan air payau, lumpur dan mangrove dekat garis pasang.

Memiliki panjang antara 4-6 cm dengan bentuk cangkang memanjang. Warna cangkang yang dimiliki spesies ini dominan kecoklatan dengan apeks agak meruncing dan lekuk sifon agak lebar serta permukaan cangkang yang kasar bertonjolan dan beralur. 


\section{Kelimpahan Gastropoda}

Berdasarkan hasil penelitian, setiap titik sampling pengamatan memiliki jumlah kelimpahan Gastropoda yang berbeda-beda. Jumlah Kelimpahan Gastropoda yang tertinggi terdapat pada titik sampling I dengan nilai 91 individu $/ \mathrm{m}^{2}$ kemudian diikuti oleh Titik sampling II dengan nilai 78 individu $/ \mathrm{m}^{2}$ dan kelimpahan terendah ada pada stasiun III dengan nilai 70 individu $/ \mathrm{m}^{2}$. Faktorfaktor yang membatasi kelimpahan adalah faktor yang menentukan berapa banyak individu tersebut dan harus mencakup sifat individu dan lingkungan.Keduanya berperan untuk menentukan batas kelimpahan spesies (Maguran, 1988).

Pada titik sampling I yang memiliki kelimpahan yang tinggi merupakan daerah di belakang hutan, sehingga perairan tersebut tidak terkontaminasi oleh limbah apapun, dengan kondisi ini maka lingkungan dari hutan mangrove menjadi tempat berkembang biak yang disukai oleh Gastropoda. Pada titik sampling II merupakan daerah perairan di perumahan nelayan. Sedangkan pada titik sampling III yang bertempat di belakang galangan kapal tongkang sehingga diduga terkontaminasi oleh limbah dari bongkar muat kapal tongkang. Dugaan ini dikarenakan bongkar muat kapal tongkang dilakukan di perairan bukan di bibir pantai, hal ini justru dapat mengakibatkan tumpahan batu bara akan langsung jatuh ke perairan dan otomatis akan mencemari lingkungan pantai. Pencemaran ini pasti akan mengakibatkan berkurangnya rusaknya ekosistem Gastropoda.

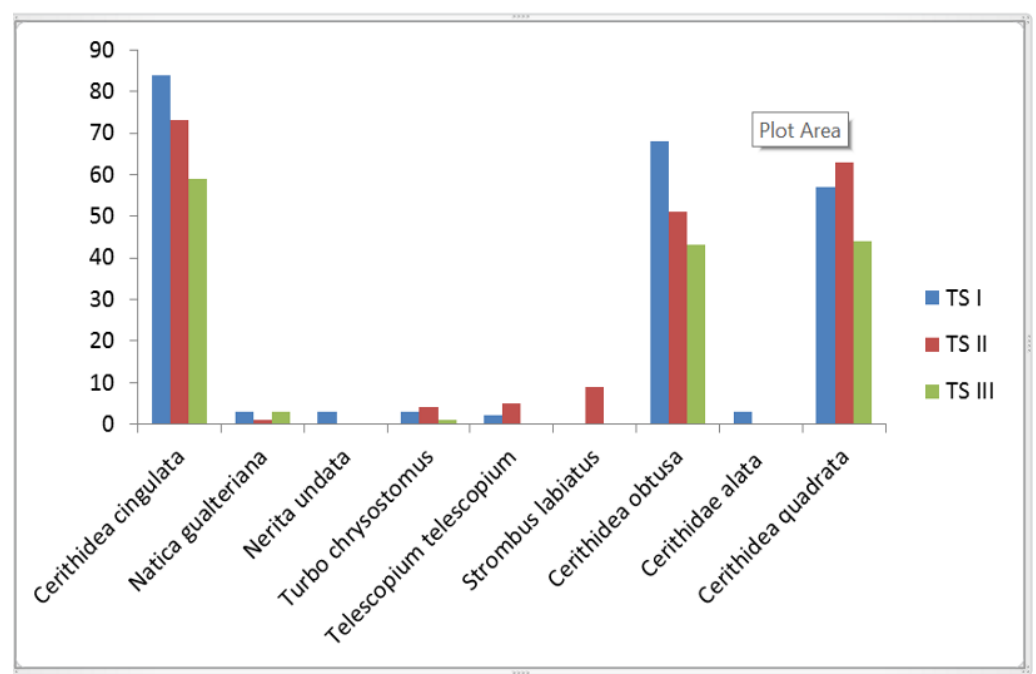

Gambar 13. Grafik kelimpahan Gastropoda di perairan Teluk Sepang

\section{Parameter Lingkungan di Perairan Teluk Sepang}

Hasil pengamatan parameter kualitas air pada tiga titik sampling selama penelitian diperairan Teluk Sepang sebagai berikut :

Tabel 4. Nilai Parameter Kualitas Air Selama Penelitian

\begin{tabular}{ccc}
\hline Parameter Kualitas Air & Pengukuran Kualitas Air & Optimal \\
\hline Suhu $\left({ }^{\circ} \mathrm{C}\right)$ & $29-30^{\circ} \mathrm{C}$ & $23-35^{\circ} \mathrm{C}^{*}$ \\
Salinitas (ppt) & $31 \%$ o & $15-35 \% \%^{* *}$ \\
$\mathrm{pH}$ & $7-8$ & $7-7,8^{* * *}$ \\
Substrat & Pasir Berlumpur & \\
\hline
\end{tabular}

Keterangan: *Simanjuntak, 2009. **Supriharyono, 2008

\section{Suhu}


Hasil pengukuran suhu di daerah Teluk Sepang yaitu berkisar antara 29$30^{\circ} \mathrm{C}$ dan menurut Simanjuntak (2009) suhu optimum yang baik untuk Gastropoda yaitu berkisar antara $23-35^{\circ} \mathrm{C}$.

\section{Salinitas}

Hasil dari pengukuran salinitas di daerah teluk sepang yaitu berkisar antara 31\%o dan menurut Supriharyono (2008) salinitas optimum yang baik untuk Gastropoda yaitu berkisar antara $23-35^{\circ} \mathrm{C}$ dan dapat dikatakan bahwa suhu perairan teluk sepang masih masuk dalam kondisi optimum.

\section{Derajat keasamaan (pH)}

Setelah dilakukan penelitian didapatkan hasil dari pengukuran Derajat keasamaan $(\mathrm{pH})$ di daerah teluk sepang yaitu berkisar antara 7-8 dan menurut Ira (2014), derajat keasamaan $(\mathrm{pH})$ optimum yang baik untuk Gastropoda yaitu berkisar antara $7-7,8$.

\section{KESIMPULAN DAN SARAN}

\section{Kesimpulan}

Pada penelitian ini dapat disimpulkan bahwa di daerah perairan Teluk Sepang Kota Bengkulu terdapat sembilan jenis Gastropoda dengan kelimpahan yaitu $216 \mathrm{ind} / \mathrm{m}^{2}$ Cerithidea cingulata, $7 \mathrm{ind} / \mathrm{m}^{2}$ Natica gualteriana, 3 ind $/ \mathrm{m}^{2}$ Trochusconus, $8 \mathrm{ind} / \mathrm{m}^{2}$ Turbo chrysostomus, $7 \mathrm{ind} / \mathrm{m}^{2}$ Telescopium telescopium, $9 \mathrm{ind} / \mathrm{m}^{2}$ Strombus labiatus, $162 \mathrm{ind} / \mathrm{m}^{2}$ Cerithidea obtuse, $3 \mathrm{ind} / \mathrm{m}^{2}$ Vexillum rugosum, dan $164 \mathrm{ind} / \mathrm{m}^{2}$ Cerithide aquadrata.
Diharapkan adanya penelitian lanjutan tentang jenis dan kelimpahan biota-biota di daerah pesisir Provinsi Bengkulu khususnya pada jenis Gastropoda, dikarenakan kurangnya data akan jenis dan kelimpahan Gastropoda yang berada di daerah pesisir Provinsi Bengkulu.

\section{DAFTAR PUSTAKA}

Fachrul, M. F. 2007. Metode Sampling Bioekologi. Jakarta.

Ira. 2014. Keterkaitan Padang Lamun Sebagai Pemerangkap dan Penghasil Bahan Organik Dengan Struktur Komunitas Makrozoobentos Di Perairan Pulau Barrang Lompo. Tesis. Institut Pertanian Bogor.

Laksmana, S. T. 2011. Lama Waktu Pemangsaan dan Ukuran Lubang Pengeboran Chicoreus capucinus (Neogastropoda: Muricidae) Terhadap Cerithidea cingulata (Mesogastropoda: Potamididae). Skripsi. FMIPA UI.

Maguran, A. E. 1988. Ecological Diversity and Its Measurement. Chapman and Hall: USA.

Mudjiono dan Sudjoko, B. 1994. Struktur Komunitas Biologi Padang Lamun di Pantai Selatan Lombok dan Kondisi Lingkungannya. Pusat Penelitian dan Pengembangan Oseanologi. LIPI. Jakarta.

Sugiyono. 2009. Metode Penelitian Bisnis (Pendekatan Kuantitatif dan Kualitatif). Bandung: Alfabeta.

Supriharyono. 2008. Konservasi Ekosistem Sumberdaya Hayati di Wilayah Pesisir dan Laut Tropis. Pustaka Pelajar: Yogyakarta.

\section{Saran}

